\title{
Water Titles of Corporations and Their Consumers'
}

Whether or not the main aim of the law should be to hold water supplies in common, placing water-right owners upon equality and apportioning the water among them, or whether water-supplies should be divided into severalty according to priorities, conceding no apportionment, the latter is in this State the prevailing system in practice, and the Water Commission bill this year to come to referendum vote plans to have the owners of water-rights officially determined and listed according to their priorities. We inay consider this evening how far distributing corporations themselves, and how the consumers under the corporation canals and reservoirs, are among the water-right owners.

I. The irrigation cases started the question. Irrigation, as it began, was the work of individual farmers diverting streams to their land in small ditches of their own. Today this is very extensively done, but there is also a large proportion of irrigation by farmers who do not go to any stream for their water, but get it out of the canal of some distributing system.

In the former case the farmer who goes to the stream itself and has possession of the streain flow owns an interest in the stream known as a water-right. Let us first consider the waterright of this irrigator. And to avoid complication with the riparian doctrine, we suppose his right to be based upon priority, that is, his grandfather was the first to use water from that stream.

A nati.al stream is a natural body of water, and a water-right therein such as this man's, located upon the stream, is a right to the continued existence of the river as a natural body of water at his point of diversion. It is not an ownership of the water of the river itself. The water itself in its natural course above, being a "movable, wandering thing", uncontrolled and unconfined by any one's agency, has no owner as a specific thing. By the California Statute of IgII (amending Civil Code section I4ro),

1 Read before the Law Students of the University of California, Boalt Hall of Iaw, Berkeley, January 29, 1914. 
it is declared to belong to the people of the State; by the language of the courts, it is and long has been declared not to be the subject of actual ownership by anyone, neither individual nor the State, just as the rain or the water of the sea is not regarded as being property of any kind. ${ }^{2}$

The water-right which he has is the intangible right to have the stream continue to flow to a certain point for him to divert it there for his use, rather than ownership of any individual water; called by the courts a "usufructuary" right."

Figuratively, the stream may be looked upon as a "water mine", from which, though owning none of the ore in place, he has a right to mine water at a certain point. As you know, for a long time this water-right in the stream has been classed in the law as real property and as private property. Often it is classed with easements or other incorporal rights in real property, but that it is a private right has for a long period been accepted without question in law-books and courts. It is taxed, it cannot be taken from hin without due process of law, he is entitled to damages for interference with it, his title to it may be quieted, it passes by descent to his heirs, it may be sold and it has the various attributes of real estate.

2 A good example of the way the courts have put this is as follows: "It is a principle recognized in the jurisprudence of every civilized people from the earliest time that no absolute property can be acquired in flowing water. Like light, air, or heat of the sun, it has none of the attributes commonly ascribed to property, and is not the subject of exclusive dominion and control . . . While the right to use it as it flows along in a body may become a property right, yet the water itself, the corpus of the stream, never becomes, or in the nature of things can become, the subject of fixed appropriation or exclusive dominion, in the sense that property in the water itself can be acquired, or become the subject of transmission from one to another. Neither sovereign nor subject can acquire anything more than a mere usufructuary right therein. $-\therefore .$. These propositions have been often stated by jurists and in judicial decisions in different forms, but it is believed that they all concur in the same general result". Sweet v. City of Syracuse, 129 N. Y. 335 .

3 This was laid down very early by the Supreme Court of California as follows: "This court has never departed from the doctrine that running water, so long as it continues to flow in its natural course, is not, and cannot be made, the subject of private ownership. A right may be acquired to its use which will be regarded and protected as property, but it has been distinctly declared in several cases that this right carries with it no speciflc property in the water itself.

In regard to the water of the stream, his rights (an appropriator's) like those of a riparian owner, are strictly usufructuary and the rules of law by which they are governed are perfectly well settled". Kidd v. Laird, 15 Cal. 161, 179. 
2. Corporate ownership does not per se alter the title. Suppose this farmer, whose diverting works are in the natural stream, divides his land among his three children and they form a corporation for convenience of ownership, farming the land together as one, the same as while their father was alive. They transfer, of course, all the property to the corporation when they form it. The corporation has now whatever title their father had. That the corporation's water-right is real property of its own and belongs to the corporation now, the same as before it belonged to the father, is evident. As the Supreme Court of California has said: "In this State a corporation's title to water, either by appropriation or prescription, has been recognized and upheld from the earliest day".4

3. Suppose, now, after farming five hundred acres for awhile, the three sons decide to cease irrigating Io acres thereof, and to furnish (as a corporation) one of their neighbors with the water for ten acres. The accepted view, both among the irrigators in practice, and the courts in their decisions, is that the neighbor becomes a part-owner, with the brothers' corporation, in the ditch and in the water title under which the ditch is kept filled from the stream. The neighbor becomes a tenant in common with the brothers (that is, with their corporation) in the "water mine".

By this transaction, which is the bargain generally made in the case put, the brothers' corporation does not engage to deliver water as a personal obligation on its part, but sells an interest in the stream itseif, so that the neighbor becomes a taker from the stream, and a common owner with the brothers' corporation in the whole outfit made up of the ditch and its water-right.

4. A different type of transaction may occur, however, depending upon the purpose of the parties. If the neighbor, instead of having Io acres he wants to irrigate, has a sawmill he wants to run, he may find that the price for onetenth interest (for example) in the water-right and ditch is more than he wants to spend; or if it is to supply a steam boiler, he may want water on occasion only, and not as a steady thing. In such cases he will not want, will not pay for, and will not think he is getting any interest in the brothers' water property. He will ask them merely to serve him from time to time so much water from their ditch at so much per inch or cubic foot per

4 Montecito etc. Water Co. v. Santa Barbara, $144 \mathrm{Cal}, 578$ at 592. 
second, paying for what he gets as he goes along, without having or thinking he has any share in the title under which the brothers get the water out of the stream. Note, now, that it was open to the brothers and the neighbor to make either bargain they chose: in the one case they chose to sell and buy a share of the water titles; in the other they did not; it was purely a matter of intention or election on their part which they should do.

5. Between these two types of transactions the difference to be kept in mind seems to me to be this: that the one who buys the one-tenth interest in the outfit gets a right in a natural waterbody (the supplying stream) and therefore in true legal sense a "water-right," while the saw-mill owner does not.

The saw-mill owner's right, not having bought any share in the "outfit", is simply a right of contract. The chief element of it is the continuance of supply which is promised. It rests upon some man's promise. In contrast to one who gets an interest in the stream itself, whose continuance of supply rises or falls upon the acts of nature alone in furnishing or withholding rains and snows on the watershed, the saw-mill, relying upon the brothers' promise, depends upon their personal duty, as the owners of the ditch, to keep it coming through. It is primarily a contract for continuous service. ${ }^{\text {ta }}$

The service in furnishing continuity of supply to the saw-mill is hence its essence; less a contract to give something, than to do something. No share in the titles is conveyed. Nothing substantial of any kind is conveyed. The only thing changing hands is the water pouring over from one ditch to another, but that is unimportant without the right of having it continue to pour over. As to the actual water pouring over, ( which, while in the stream, was "publici juris") it has become a species of private property so long as reduced to possession in the ditches, and the authorities say that it is personal property (which seems to me for a number of reasons to be correct), excepting one authority who says it is real property, and would thereby reach the conclusion that the saw-mill owner was buying chunks of real estate to run his saw-mill with. ${ }^{5}$ Be that as it may, it is unimportant entirely

4 (a) Equity, for example, probably will not enforce specific performance of it, under the rule that contracts for continuous service, like the building of a house, running a steamboat, and so forth, are beyond the power of equity to specially enforce.

See 1 California Law Review 484. 
whether the water pouring over is realty or personalty. Break the continuity of the coming and the saw-mill stops in either case. The gate between the supply ditch and the saw-mill owner's ditch being closed, the water in the latter, be it realty or personalty, would be gone in an hour, and any single ditchfull of water would be of no importance, whatever its legal nature. The right of continuance is the only important thing in the transaction, and, in the saw-mill case, the saw-mill's right of continuance consists simply in the personal duty of the brothers to contimue to keep their contract, and is not a right of ownership in the stream from which the brothers get their supply. In the irrigation transaction such a right of ownership, or "water-right", did change hands, but not in the saw-mill case. This difference underlies the questions we are about to reach.

6. To carry on the illustration in the irrigation case, suppose the water titles to be divided among two or three more neighbors, each becoming a part-owner in the general "outfit". It may become convenient for them, after a while, to transfer their shares in the titles back to the corporation, so that the corporation owns the whole title again, and in exchange take shares of stock in the corporation, under an arrangement that each share shall represent a certain portion of the water-supply. In that event a "mutual water company" results, in which the consumers are the stockholders, and, while the whole water-title is vested in the corporation, the beneficial interest therein belongs to the stockholders. The consumers of the water, that is, the irrigators, still remain the owners, in substance, of the natural source of supply, and the corporation is in the nature of a co-operative association. ${ }^{6}$

Corporations of this kind are very common in irrigated regions, but for this evening's purpose I can only stop to distinguish them

${ }^{6}$ A rather good description of the status of water titles in such mutual companies is given as follows by the Federal Court for Idaho: "In the case of such corporations, strictly speaking, the legal title to the canal and appurtenant water right is in the corporation, whereas the water is used upon land belonging severally to the individual stockholders, and therefore there is not absolute identity of ownership of the irrigating system and the irrigated lands. No reason, however, is apparent why such a canal should, for the purposes of taxation, be differentiated from a canal directly held by the water users as joint owners thereof. The corporation but holds the naked legal title in trust for its stockholders, and the owners of the land as stockholders are therefore the beneficial owners of the canal, possessing all the power of control and disposition incident to full ownership". Spokane Valley Ettc. Co. v. Kootenai County, (Idaho) 199 Fed. 481. 
from public service companies. A California Statute of $1913,{ }^{7}$ passed, I understand, at the request of the Railroad Commission, declares that mutual companies are not public utilities nor subject to control of the Railroad Commission, which is but declaratory of rulings previously made by the Supreme Court. ${ }^{8}$ Difficulties sometimes arise as to whether a given company is a mutual one or not; thus, in the Imperial Valley cases involving the California Development Company, the mutual form was used in organizing subsidiary companies in order to accomplish for the Development Company a public service result without the corresponding responsibilities, and the Supreme Court of the State and the United States Circuit Court of Appeals have expressed conflicting views as to the status of the Development Company. The Supreme Court of the State felt bound by the form, while Judge Morrow considered the substance of the project, as he saw it, to be more important. ${ }^{9}$ However, the State Supreme Court in a later case intimates that in these matters it will not always be bound by the form. ${ }^{10}$ And the safest view for a law student to take is probably that form without substance has a weakness in it that does not make it a sure test between private and public service.

7. Suppose, now, that the brothers (whom I will hereafter term the "corporation") decide to give up their own farming entirely, and distribute all their water to any of their neighbors who care to receive and pay for it, that is, they hold out their supply indiscriminately to the public, in exchange for payment. No stock is issued to the consumers, and we leave mutual companies aside from now on. The corporation is now engaged in public service, that is, in serving a public use. By.so doing, it brings itself within Article XIV of the Constitution "of "California declaring its future operations to be subject to public regulation. Engaging in service to the general public brings public duties. Certain duties must be performed, under supervision of the Railroad Commission, the chief duties being to serve all the public (or some class thereof) to the extent of capacity of the system, without discrimination,' at

7 Chapter 80.

8 See Garrison v. North Pasadena etc. Co., 163 "Cal. 235, 124 Pac. 1009.

o See Imperial W. Co. v. Holabird, 197 Fed. 4; and Thayer v. California Development Company, 164 Cal. 117, 128 Pac. 21.

10 Copeland v. Fairview, (Cal. Sup.), 131 Pac. 119. 
reasonable rates, and without unreasonable conditions. The right of the State to enforce these duties rests upon the police power, which means its sovereign power to regulate the conduct of its corporations and citizens.

8. Outside of water cases, these public duties are unconnected with property or title questions, as a rule. Resting upon the sovereiguty or. regulative power of the State, they must be obeyed whether the title to the natural supply belongs to the corporation or whether the corporation is only a lessee, or whether the consumers own the water-right titles. The duties stand on their own legs, as representing the power of the State as a government to regulate public business, be the ownership of the property in whom it may. A familiar illustration is in the case of railroads, where the title is private in the company, while the business conducted is regulated by public authority. "And, generally it is true that, even when property is dedicated or appropriated to public use for gain by persons or private corporations, the title and ownership is private and the only interest of the public is that of beneficiaries of the use or trust."11 Outside of water cases no question of this exists.

9. But in water cases there is much discussion, especially in irrigation cases. The Colorado view is that the irrigators become part-owners in the water-titles and distributing canals (just as when the brothers supplied a neighboring irrigator,) whether the service be private or public. The present ruling of the California authorities is, on the other hand, that after public use attaches the whole title must remain in the distributor, and that the consumer under the canal can have no "water-right" as a share in the system.

Io. The ruling to this effect in the Supreme Court of California was made in the cases of Leavitt v. Lassen Irrigation Company, ${ }^{12}$ and Lassen Irrigation Co. v. Long, ${ }^{13}$ and the Railroad Commission of California has expressed agreement with the principle there declared.14 In the previous case of Stanislaus W. Co. v. Bachman ${ }^{15}$ the Supreme Court of California had held the irrigator to be the owner of a share in the company's water titles

11 Thayer v. California Development Co., 164 Cal. 117.

12157 Cal. 82.

$13157 \mathrm{Cal} 94$.

14 Palmer v. Southern Cal. etc. Co., 2 Cal. Ry. Com. 43.

$15152 \mathrm{Cal} .716$. 
and canal, as an appurtenance to his land. The Lassen cases recognize this as what happens in irrigation transactions between private interests, but hold that the law will not permit it where the public interest has intervened, and, in effect, overrule the Bachman case where the distributor is engaged in public service. They hold the consumer's right to be not a private right of property, but a public right of much the same nature as the right of a member of the public in a park. Each member of the public has a right to go into Golden Gate Park and walk or, drive and use it in all ways appropriate to parks, but this right is in no sense private property. When a water-supply is devoted to public use no consumer can, these cases hold, own a "water-right" as a private share of the supply, any more than he can own a section of the public park. The actual water titles remain in the distributor, just as in the case of railways, gas companies, telephone companies, and so on. The consumer's right of service is a "time-totime" arrangement, as in the saw-mill case, an arrangement on the part of the company to continuously do something and not an arrangement to transfer any titles. For a public service company to attempt (as the incorporated brothers did before entering public service) to convey a share of its titles to any individual consumers and give them a private part-interest in the "outfit" instead of a public right of service as above defined, would, the Lassen cases held, create a private right in a public trust, and be subversive of the public use. Such attempt is held to be affirmatively prohibited. The consumer gets no "water-right" title; no interest in the real property of the water-system; no private appurtenance to his land.

II. The Colorado Court, and Judge Morrow here, do not acknowledge such prohibition. In Colorado and numerous other Western courts the irrigator under a public service distributing ditch is considered a "water-right owner" in the same terms as in the private arrangement first noted, between two neighbors creating a tenancy in common. As stated in an Idaho case following Colorado, "The water-right became detached from the canal, and became attached to a particular tract of land."16 And in the United States Circuit Court for California Judge Morrow made the same ruling, saying:- "The water-right must, therefore, be the

${ }^{16}$ Hewett v. Great Western Co., (Idaho), 118 Pac. 296. 
right of the consumer attached to his land, and not the right of the complainant attached to its canal system."17

This is, contrary to the Lassen cases, a view much prevalent in irrigated regions, both here and elsewhere. It became established first among the water-users themselves, and the Colorado courts only put it into a setting of legal explanation. These explanations, together with the explanation given for the contrary view in the Lassen cases, lead to different results upon matters of importance which water questions today are threshing out; and I shall here briefly note the bearing upon (a) acquisition of rights, (b) priorities among consumers, (c) parties in general determination proceedings, (d) charges for "perpetual water rights", and (e) valuation of the distributing system in taxation or rate cases.

12. The first explanation has a particular bearing upon the acquisition of rights. This explanation is that the consumer is an owner pro tanto of the water-right in the supplying stream, because the appropriation of the stream did not come into being until actual use was made, and this use, being made by the consumers, constituted them to be the appropriators of the stream, and not the canal company. This is very strongly ruled in the Colorado cases. It opens the question, what is the status where new irrigation companies are being started and before they have secured consumers for their supply? It would seem that this view would say the company has no title at such period. Yet it is taxed as owner of the title in such cases, ${ }^{18}$ and it is allowed relief against diversion of the water by a hostile enterprise. This explanation, therefore, involves inconsistencies. ${ }^{19}$ A way of reconciliation has been sought in Wyoming, to some extent, by issuing certificates of appropriation to both the company, and, as they settle under the canal, the consumers; recognizing sometimes the

17 San Joaquin etc. Co. v. County of Stanislaus, 191 Fed. 875. See 1 California Law Review 85.

18 Wyoming etc. Co. v. Farlow, (Wyo.), 114 Pac. 635.

19 The Supreme Court of Montana recently noted this. Speaking first of the view that the company owns the titles, the Court says: "Upon the theory thus advanced, the claimant who proceeds under the statute, and performs the acts required as set forth above, has a completed appropriation of water upon the completion of the work on his ditch, canal, or other means of diversion, even before the water is actually applied to a beneficial use. The correctness of this view, we think, is emphasized by consideration of the opposing doctrine. In Colorado it is held that actual application of the water to a beneficial use is a 
one and sometimes the other as the owner of the water right, as expediency may make advisable. But the matter is in a state of uncertainty and confict.

I3. The second question is in regard to priorities between consumers. Viewing the consumers as appropriators and waterright owners in the stream from which the distributing canal heads, the Colorado law applies to them the same rules as to appropriators of streams, and arranges their rights in order of priority of use. The Railroad Commission of California, however, following the Supreme Court in the Lassen cases, has denied priorities among consumers, and enforces pro-rating equally among them when a deficiency of supply comes. ${ }^{20}$ But Colorado, considering the consumers as appropriators and owners upon the supplying stream, holds to the rule of priorities among them, and even has ruled that a statute introducing prorating in times of deficiency is in Colorado unconstitutional.21

r4. The third question is very similar, arising out of the determination of priorities by the Water Commission or other tribunal under water codes. The prevailing law and practice under water codes is to consider only the main canals heading in the natural stream. Individual irrigators under those canals are not passed upon by the Water Commission. The Colorado decrees likewise are held applicable only to companies, or "carriers", as the

necessary prerequisite of a completed appropriation, and this doctrine is followed in some of the other states. Our act of 1877, above, specifically recognized the right of an individual to appropriate water to rent or sell to another; but if the Colorado doctrine be invoked here, such individual could never make his appropriation, for, under the Colorado theory, the user and not the first individual would be the appropriator, and this is the only consistent position to assume, if actual use is a necessary step to a completion of the appropriation". Baily v. Tintinger, (Mont.), 122 P. 575.

20 "It is also well-established in this State, contrary to the doctrine in most of the other Western States, that in the case of a public service water company, at least as between consumers of the same class, there is no priority, and in times of shortage the supply of water must be ratably apportioned". Palmer v. So. Cal. etc. Co., 2 Cal. Ry. Com. 43 at 53. Writ of Review denied by Supreme Court, January 21, 1914. "As between consumers who have been voluntarily admitted to participate by the corporation in its supply of water or been required to be supplied by an order of the railroad commission, in times of shortage there shall be no priority or preference, and such corporation in times of shortage shall be required to apportion such supply ratably among its consumers". California Statutes 1913, Chapter 80.

21 Farmers' etc. Co. v. Southworth, (Colo.), 21 Pac. 1028; Farmers' etc. Co. v. White, (Colo.), 75 Pac. 416. 
owners, and assign the priorities to them. ${ }^{22}$ Here is seemingly an important inconsistency with the position just mentioned in the same State that the consumers are the owners of the priorities. It is also of much practical importance if we are going to create a water commission to determine rights. If the individual irrigators, of whom there are thousands, are not to get any official recognition in the proceedings, the hope sometimes held out to them that under a water commission act each would get a deed from the State for his water, the same as he has a deed for his land, would not be realized. The adjudication proceedings would not regard him as owning an actual water title. This is illustrated by the Colorado situation, where the individual irrigators are said to own the water titles and not the company, and yet the adjudication of priorities runs wholly in favor of the coinpanies, and passes the consumers by.

15. The fourth question is in regard to charges for "perpetual water rights". It is a very general practice for an irrigation company to make its charges $\$ 50$ to $\$ 100$ per acre (payable in ten annual installments) for conferring a water right upon the consumer, and then an annual rate is added for delivery and maintenance. If the title was originally the company's and if the question of the effect of the transaction is one of intention, such a charge is good, being the price of a share in the water system. Thus in Nebraska it is held that the irrigation company does not own the water-right but that the consumers own it, and a charge for, a water-right against the consumer when he gets his water-right from the company by settling under the canal is held a valid charge. ${ }^{23}$ As already said, the intention of the parties in irrigation is often to have this kind of a transaction, and the consumers then pay such water-right charges voluntarily, and are, in practice, considered to be purchas-

22 "The proceeding does not contemplate that there shall be an adjudication of the relative rights of the owners or consumers of water under any particular ditch, as between themselves, but only the relative priorities of the ditches, canals or reservoirs." Coombs v. Farmers' Etc. Co., (Colo.), 88 Pac. 398.

23 "The argument that the corporation could not grant a perpetual water right we think is not tenable. The right to have the water from the river conveyed to the head gates of the respective contract holders and their assigns is of the nature of an easement in the ditch. This being so, it could be sold and conveyed, and may be granted in perpetuity". Fenton v. Tri-State Land Company, (Neb. 1911), 131 N. W. 1043 . 
ing a water-right as an interest in the supplying stream and distributing system. To bring the matter close home, this University considers itself the owner of a water-right which it has bought and paid for upon that basis. ${ }^{24}$ But if the Lassen cases apply, the company can give, and the consumer gets, only a right of service of a public nature, and no water-right as private property, and any charge in addition to the annual delivery and maintenance rate is charging for the privilege of exercising a public right. In this view, consequently, the "water-right" charge in addition to the annual rate has been held void, partly because without consideration (being for a "water-right" property which the consumer does not get), and partly because in this view it is against the law for the public service company to charge anything in addition to the service rates. The right to be supplied being under this view a public right, it cannot be charged for in addition to the rates. The California Railroad Commission, whose view of the law upon all these questions is in accord with the Lassen cases, has therefore ruled that the "water-right" charge in question is invalid. ${ }^{25}$ In the United States Courts for this State this is a question upon which there were numerous decisions both ways until Judge Morrow, a few months ago in an opinion from the United States Circuit Court of Appeals, reviewed the former decisions and placed the Federal Courts in line with the ruling that such "water-right" charges are illegal. ${ }^{26}$

16. The fifth question is in valuing the distributing system for taxation, eminent domain condemnation, or rate-fixing. If

24 " $U_{p}$ to July 24, 1906, no rights to water from its canals had been sold by the Yolo Consolidated Water Company. On that date the Company sold to the University of California a contract-water-right on the Capay and Winters Canal for the University Farm of 779 acres near Davis. The water-right is for 1 cubic foot per second for each 160 acres, and the price paid was $\$ 5$ per acre. The right is attached to the land and made to run with it. The contract also provides for an annual water rental of $\$ 1.50$ per acre for the acreage actually irrigated each year." Bulletin 207, Office of Experiment Stations, United States Department of Agriculture.

25 "The preliminary charge of $\$ 50$ per acre made by the company before it will deliver water for irrigating purposes is objectionable and should not be allowed. If this is a public utility with water available, it must on demand furnish to a consumer water at its established rates. A public utility is such on the theory that every one under its system has a right to its service, and this theory is violated when this right must be paid for." In re Rates etc., San Gorgonio Water Co. etc., 2 Cal. Ry. Com. 710.

${ }^{26}$ Imperial W. Co. v. Holabird, 197 Fed. 4. See also San Joaquin etc. Co. v. County of Stanislaus, 191 Fed. 875. 
the consumers own the water-rights in the natural source of supply, no value thereon can be claimed by the company; while if the Lassen cases govern, the consumers do not own any "waterright", and it might be said that the company owns it and is entitled to valuation on it. The Railroad Commission of California, whose view of this general subject coincides with the Lassen cases, seems to take the latter view, that the water-rights belong to the company and are to be valued. ${ }^{27}$ On the other hand, Judge Morrow has held the consumers to own the water-rights and not the company, under the law as it already stands, and has denied to the company any valuation for water-rights. ${ }^{28}$ In the Spring Valley rate cases, the matter has, as yet, remained an open question. ${ }^{29}$

I7. These five questions are all of them points of conflict today. The conflict began at the stage where public use entered the discussion. Before that point came in, the question was one

${ }^{27}$ It reaches the matter for the future by inserting a clause in the pending water commission bill requiring new appropriators hereafter to waive this element of value before a license will be given them; enacting: "And every licensee or permittee under the provisions of this act, if he accepts such permit or license, shall accept the same under the condition precedent that no value whatsoever in excess of the actual amount paid to the State therefor shall at any time be assigned to or claimed for any permit or license or for any rights, granted or acquired under the provisions of this act, in respect to the regulation by any competent public authority of the services or the price of the services to be rendered by any permittee or licensee, his heirs, successors or assigns or by the holder of any rights granted or acquired under the provisions of this act, or in respect to any valuation for purpose of sale to or purchase, whether through condemnation proceedings or otherwise, by the State or any city, (etc.) of the rights and property of any permittee or licensee, or the possessor of any rights granted, issued, or acquired under the provisions of this act." Cal. Stats. 1913, p. 1012 at 1025 , Section 20.

28 "It follows that under the law of this State it cannot be valued as a property right upon which the complainant is entitled to an income from the water rate to be paid by the consumer. I do not overlook the fact that the right of the carrier to divert water from a running stream has been recognized in this State, in some instances as a water right vested in the carrier, and that valuations of such supposed rights have been admitted by the consumers; but the consumers have not admitted that right in this case, and I do not find it established by law, and the evidence is not sufficient to make it a law growing out of custom, I conclude that it. is not a right that complainant is entitled to have valued as its property right in this case." San Joaquin etc. Co. v. County of Stanislaus, 191 Fed. 875, (Sept. 1911).

29 "No question has been raised as to the propriety of including water rights among the properties to be valued, upon which complainant is entitled to return in the water rates. The onlv difference between the parties is as to the proper valuation." Spring Valley W. W. Co. v. San Francisco, 192 Fed. 137. 
of intention whether the "brothers" corporation sold a part-interest in their "outfit", creating a tenancy in common, or whether they gave only a right of service, as in the sawmill case, transferring no titles. But after public use entered, there came a parting of the ways. Colorado chose one way and California the other, each, with varying consistency ${ }^{29 a}$, crystallizing into law its own view of what, before, was a matter of choice to the organizers of projects.

I8. If, as the California cases now hold, no "water-right" can pass out of a public service company to any consumer, it seems clear that it passes to him in no other way, and title remains in the company. For it is property, and must belong to someone, and there is no other place for it to be. True, there is some current contention that the water titles may belong to neither the consumer nor to the company, but to the "public" or "State". The "public" in reference to distribution of water comes back to the consumers, however, as they are the public for whom alone the power of eminent domain is exercised in acquiring additions to the system, and who alone can be considered in defining a given use to see whether it is a public use such as to be subject to public regulation. If the water titles do not belong to them then they do not belong to the "public." As to the explanation that they belong to the State at large, the State's position in reference to waters is jurisdictional; its police power. This is regulative in nature, and is in the nature of sovereignty rather than proprietorship, as mentioned before. True, statutes sometimes declare that waters are the "property of the State", as in the California Civil Code Section r4ro. Such declarations are in reference to the corpus of the water, and are a variation of the statement of the "negative community" theory. As first pointed out this evening, whether the State owns the corpus or substance of the water, or whether no one owns it (the State's office being regulative only), is not the question involved; the water-rights under question are the usufructs in the streain which the law has allowed citizens to acquire and which may belong to the consumers or to the company whether the corpus in the stream be the property of the State or of no one. To recall

29a See City and County of Denver v. Brown, (Colo.), 138 Pacific 44, the most recent expression of the Supreme Court of Colorado, which derogates from the view taken in the previous decisions under consideration. 
a figurative comparison I used before, the natural stream is somewhat like a "water mine" in which the ore may be viewed as belonging to no one, and publici juris, or, if you will, the property of the State, but with rights outstanding in individuals to continuously mine it. That the ore in place belongs to the State does not necessarily prevent the mining rights from being property of individuals, whether the company or its customers. So that if, as the California cases now hold, the law will not permit the water-rights titles in the natural stream to become the consumers' by transfer from the company pro-tanto as they settle under the distributing systein, then the title remains in the company, subject, of course, to the State's regulative sovereign jurisdiction of control. ${ }^{30}$

I9. The present California view that no "water-right" passes to consumers, and that the transaction is one of service only, beside being most in accord with the usual law of public service companies, expresses also the belief in practice in water distribution outside of irrigated regions. The distribution of water for domestic use in cities has not heretofore been thought to give to the householder a right of ownership in the rivers, if any, froin which the supply is drawn and accumulated in the reservoirs. So

30 "We find law writers and courts saying that the waters of the State belong to the people (as they do by the constitutional provisions in some Western States) by reason of the two sections of Article XIV of the Constitution, which do not remotely bear upon the subject, and only make the agency which has by any means lawfully acquired the right to be in control of a quantity of water, subject to regulation when such agency sells, rents or distributes such water to the public or a portion thereof". "Palmer v. Southern California etc. Co., 2 California R. R. Commission 43 at 55. . . In denying a writ of review in this case the Supreme Court said last week (January 20, 1914): "The theory that the water of a non-navigable stream in this State is in some sense 'public water' has been advanced before. It has been claimed that a diversion of water under the provisions of the Civil Code (Secs. 1410 to 1422 ) constitutes a grant of the water by the State to the appropriator. The idea may have arisen from the statement sometimes made in the decisions that the riparian owner has no right in the corpus of the water, and that running water cannot be made the subject of private ownership, that the right to use the water of a stream, 'carries no specific property in the water itself.' This is far from saying that the property in the water is vested in the public, either for general use, or as the property of the State. The doctrine that it is public water, or that it belongs to the State because it is not capable of private ownership, has no support in the statutes of the State or in any decision of this court". In denying a rehearing, the Court added that existing rights are not affected by Section 1410 of the Civil Code, as amended in 1911 by the legislature to declare waters the property of the people of the State. 
likewise the miners of Grass Valley to whom the South Yuba Water Company delivers water to wash gold in quartz mills. The intention of these transactions as shown by the accepted beliefs of water users creates no ownership in the consumer, and the waterright titles must consequently remain in the company. And also in the class of irrigation systems where irrigators pay simply an annual rate and no other charge, they do not look upon themselves as "water-right owners", but merely as "renting" what they need from time to time; that is, as having a right of service, but no ownership in the water system or its appurtenances. In such cases as these where annual service rates only are paid, whether for irrigation, or city household supply, or mining or manufacturing uses, no sale of an interest in the distributing system is contemplated by anyone; the consumer is not a "water-right owner" and gets only a right of service from time to time; the company is not entitled to make (nor does it actually make) an extra water-right charge, having transferred none of its rights; as the retained property of the company the water-right is taxable to the company and is entitled to valuation as part of the company's property in fixing its service rates under public regulation. These are the deductions in California from the Lassen cases, and they accord with the usual law of public service companies, as well as with the common view of the situation in such services.

20. But, at the same time, the Colorado view is more in harmony with common belief in the class of irrigation cases where a perpetual "water-right" is specially paid for. Where the arrangement is that the company charges irrigators $\$ 50$ to $\$ 100$ for a perpetual water-right, as it is called, the prevailing construction of the transaction in practice among water users in irrigated regions is that a share in the irrigation titles and system of the company is transferred, creating a water-right for the consumer in the supplying natural stream (giving him a "mining-right" in the natural stream) and making it, as incorporeal real property, an appurtenance to the consumer's land. If this irrigation custoin is given effect, then where the irrigation company receives a separate price for a share in its system and such rights are held out to all who apply, the situation is that the company acquired a water-title when it created its system; it parts pro-tanto with its title when it sells water-rights to consumers; the latter get (and the charge for it is valid) a "water-right" as property in the supplying stream and a property in the distributing system; and the company is not there- 
after entitled (to the extent of outstanding "water-rights") to any valuation thereon in rate fixing. Of course, any discrimination or oppressive conduct upon the part of the company would still remain illegal.

The reason assigned for refusing to recognize the latter type of transaction in California seems open to argument. The Lassen cases hold that type prohibited on the ground that to confer upon a consumer such a share in the titles would create a private right in a public use, which would be true if some consumers were given such water-right ownership, and some not, under the same distribution. But if such ownership goes without preference to all under a given system, the basis of the law of public service,-the principle of reasonable service by the coinpany equally to all-does not seem impaired. The company remains subject to public control as much as before, and the equality among consumers is not disturbed. It would in the end result, it is true, in public ownership of the system, after the coinpany's water-titles have been completely parceled out this way to its consumers; but if that is the intention of the parties, I do not see that the law prohibits them from voluntarily accomplishing it if all concerned are agreeable thereto.

That all concerned are agreeable thereto is not a question of proof in separate cases. It it a matter of prevailing attitude or custom in the irrigated regions. The Supreme Court of the United States said in a somewhat related (although not identical) matter:- "Those facts must be general, notorious, and acknowledged in the State, and the State courts may be assumed to be exceptionally familiar with them. They are not the subject of judicial investigation as to their existence, but the local courts know and appreciate them". ${ }^{31}$ That is, the Colorado Courts upheld such "water-right" titles in consumers simply because the irrigation cominunities about the judges were talking and thinking that way, and the courts merely acted upon the general understanding. And in cases where a "perpetual water right" purports to be sold, they could be upheld as an exception to the general law of public service companies, upon the basis of that prevalent understanding.

2I. The matter is, however, as you see, unsettled. The waterrights, as ownership interests in the natural source of supply, must

31 Clark v. Nash, 198 U. S. 361. 
belong either to the company or to the consumers, one or the other. The present view of the Railroad Commission and Supreme Court of California is that in all cases they belong to the company, and the consumer has no water-right ownership as property, which involves that initial "water-right" charges are invalid, but the company is entitled to "water-right" valuation in valuing its property for rate fixing. On the other hand, the view of the United States Circuit Court of Appeals for, this circuit and the view of the courts of Colorado and other irrigation States is that the consumers have such ownership and the company, as between the two, does not own water-rights, which involves that (to the extent of outstanding "water-rights") the company is entitled to no "water-right" valuation in valuing its property for rate-fixing, but it ought to involve that the initial charge for the "water-right" sold to the consumer is valid.

As between these two views, the former is the one most in harmony with the general law of public service companies. The latter, however, by custom in irrigated regions, is what is acted upon in practice under irrigation systems where a "perpetual waterright" purports to be sold to the consumer.

San Francisco, Cal.

SAMUEL C. WIEL. 